\title{
Literary Symbols and Religious Belief
}

\author{
By SVEN LINNÉR
}

Of all the world's religions, I shall here only be dealing with Christianity; this is the religion I know something about. I also impose strict limitations in the matter of literary examples, which are taken predominantly from modern Swedish literature. But I naturally hope that the views presented here will also prove applicable to other religions and literatures.

Characteristic of the modern situation I have in mind is the lack of any distinction between the languages of belief and non-belief. Thus, over a wide area, a believer on the one hand may use symbols which are in no way recognisable as specifically Christian, and may do so even when he wishes to portray experiences of a profoundly religious character; as reader, he can also recognise such experiences in the symbolism of the non-believer. A non-believer, on the other hand, may use Christian symbols without enabling us to attribute to him any conversion to faith.

Let me begin by quoting an example from The Brothers Karamazov; the point in question might be called a religious concept rather than a symbol, but it can still serve to illustrate the tendency to which I refer. In the conversation between Alyosha and Ivan (Chap. 3, Book V), Dostoyevsky confronts belief with denial. On one point, however, he lets the brothers agree, that is in the belief that one must "love life more than the meaning of it"1. Here the author, himself a devout Christian, has found a formula which was probably intended to be acceptable to the sceptics too among the novel's readers. The concept of "life", as used in the novel, builds a bridge between belief and non-belief.

That the two Karamazov brothers are united on this point is of interest and significance precisely because they disagree fundamentally in other respects. This may serve as an illustration of what is the basis of my subsequent argument, namely the notion, clearly controversial, that there is a tangible difference between believing and not believing. At one level, where the brothers talk of "life", the division between the two is admittedly hard to distinguish, even invisible, but at other levels it is clear and all-important. There is a wide gulf between their respective positions. Only when we realise this, do we understand how remarkable it is that they can be united in the same devotion to "life".

The formula on which Ivan and Alyosha are agreed concerns the meaning

${ }^{1}$ Dostoevskij 289. The passage is quoted in its context in Linnér 1975, 159. Dostoevsky's

concept of "life" is studied in ch. VI, $141 \mathrm{ff}$., "Life versus the meaning of life". 
of life and thus poses an existential question. My account here is limited to questions of this type, that is the meaning of life (or the cosmos, or existence), man's guilt, man's confrontation with death. One could of course claim that religious belief colours our whole range of experience, and that it is therefore misleading to limit the comparison to a few so-called existential themes. Should one not be able to observe equally interesting differences, or equally problematic points of concurrence in other areas too-in the contexts of love, happiness or unhappiness in work, the encounter with nature, social conflicts etc? This is perhaps true, but my account would then require the scope of a book. In an outline of this kind, I consider it permissible to concentrate my argument on a few main points.

And now to my Swedish examples. Almost twenty years ago, Artur Lundkvist was subjected to an unusual and overwhelming experience; he was caught in an earthquake. This is the subject of his collection of poems, Agadir (1961). In one of the poems he writes that God "was nowhere to be found"; for those engulfed there was only a vacuum, "only darkness endlessly waiting, unaware of its waiting" ${ }^{2}$. In the following poem the atmosphere has however changed and the poet testifies to God's presence and power, and our duty to surrender ourselves to his will.

-Just as I fell down into darkness I felt that God existed, it seized me like fear and rejoicing: God let his presence be known,

showed his power over the world, showed that against God there is no recourse but God,

no buildings, no walls, no inventions, no machines mean anything to God, he sets the deep in tremors and all our certainty is crushed like straw,

his will alone sustains all living things, penetrates everything, more immanent than water and air.

What a mistake to seek him, when he is already present in everything, embracing and filling us,

we have only to surrender, to want nothing outside his will,

God has the same inescapable love for everyone,

for me whom he allowed to survive, filled with the knowledge of his presence,

for all those who died in the moment of disaster, happily united with him, for all those who still move between life and death, imprisoned in the ruins,

those he has given time for insight and transformation ${ }^{3}$.

This poem-admittedly cut and revised-has been included in the section, Hymns for Reading, in Hymns and Songs 76, published by the Swedish Church $^{4}$. This is not hard to understand. Here is the account of an ex-

\footnotetext{
${ }^{2}$ Lundkvist 81.

${ }^{3} \mathrm{Ib} .83 \mathrm{f}$.
}

4 Cf. Psalmer 1976, 194. 
perience which the believer can recognise, or at least regard as exemplary. But does it follow from this that Lundkvist himself should be called a believer? Notice that it is here a question of how, in religious terms, one should consider the poet, and not the text he has written.

If anyone wishes to interpret the poem as evidence that the poet in a moment of trial and grace has found God, then the commentator must note with disappointment that the production of subsequent years (soon two decades) bears little sign of this encounter. An alternative interpretation emerges instead. When Lundkvist is about to formulate his extraordinary experience-perhaps when he was still in the middle of it-it was the language of religion which offered itself: we know that he had learned this language as a child. With this type of interpretation we avoid calling the poet himself a believer, and thereby avoid the unpleasantness of treating faith as something a person may have at one moment and then lose again.

I have cited Lundkvist's Agadir poem because it provides a case where a literary text can be unconstrainedly characterised in religious terms, but where the poet's own religious position remains difficult to define. For what are the necessary criteria for a person to be called a believer?

The need to maintain the distinction between the religious content of a single statement and the religious position of its author emerges clearly as one studies a notebook in which the young Pär Lagerkvist, during the first World War, recorded aphorisms, drafts of poems etc. Under the heading "On Death. An Essay" we find a number of reflections, including the following: "One day after I have been searching in vain for something in my books, these words suddenly come to me and they seem to me wonderful, and more than this: I a poor sinner-"

Further on in the notebook he has written down the Lutheran General Confession word for word from the beginning "I a poor sinner" upto "Holy and righteous God-". Two theses on the pages opposite to the ones quoted show the state in which Lagerkvist found himself at the time. One says: "As far as God is concerned, I should like to say: [. . . I do not believe You exist. But I must believe it". The other says: "Those who have never been frightened by life have never been aware of it".

Lagerkvist had heard the General Confession countless times as a child in Växjö Cathedral, where his family regularly attended Sunday Service. But in his last years at school he had abandoned the faith of his home: "one must break away", as he puts it in the autobiographical Guest of Reality When - half a dozen years later-he now requotes the words of the General Confession, what does it mean? A couple of years ago we were still limited to the study of texts he himself had published. We now, however, also have his notes and manuscripts available, and we know more than before about his development. It would not be unreasonable to interpret his note on the

${ }^{5}$ Lagerkvist 1925, 136. 
General Confession as the expression of a return to his childhood faith, a secret confession which admittedly did not later achieve fulfilment.

But this is not the only possible interpretation. The notes can also be read in such a way as to mean that Lagerkvist has understood the words of faith as relevant to others besides believers; in this case to himself. Much of what he wrote during this stage of his development could be cited in favour of such an interpretation. (I am thinking principally of the artistic manifesto in Word Art and Pictorial Art (1913) and its realisation in Motifs (1914).)

It is not however my purpose to attempt to solve a problem in Lagerkvist studies, but rather to provide a reminder of two principles of interpretation which we can choose between, and which give different results. In one case we read the individual text according to the linguistic usage prevalent in the writer's environment; in the second case we play closest attention to his own use of language and symbol as we see it in all his work, particularly in the parts which are chronologically close to the problematic text. By the latter method, it is obviously far more difficult to characterise the young Lagerkvist as Christian, although we find in his writings a text taken from the lithurgy. (The corresponding observation is true with regard to Lundkvist's Agadir poem referred to above.)

In another Lagerkvist text, which I shall quote shortly, the symbolism is by contrast unspecific, seen from a religious point of view. This does not prevent the text from being interpreted in a Christian sense. In the poem Who are you, standing turned away? (in Genius, 1937) an "I" addresses an unknown figure turned away, a "you". No dialogue is established, perhaps the person turned away is unaware of being addressed, this is not explained. The text of this short poem is as follows:

Who are you, standing turned away?

Standing with your unknown face turned against the evening.

Others I know but not you,

Your countenance is hidden from me like a stranger's.

When shall I see you?

No. You I shall never see.

But one day I shall be you, be your turned away face, open against the evening ${ }^{6}$.

In one respect this text has a biblical ring. The averted/revealed face is one of the Old Testament's great symbols for the relationship between man (or Israel) and God. The concepts which the modern poet uses to indicate the relationship between the "I" and "you" of the poem belong to the sphere of the bible.: face / countenance, turned away, hidden, stranger. The lan-

${ }^{6}$ Lagerkvist 1937, $48 \mathrm{f}$. For a more detailed analysis of the poem, cf. Linnér $1971,166 \mathrm{ff}$. 
guage has a biblical tone, especially in the lines "Your countenance is hidden from me like a stranger's./ When shall I see you?". Lagerkvist has thus taken over one important element from the biblical relationship with God: that this relationship is decisive, the one thing needful. The technique is characteristic of him. His religious dilemma borrows symbols-and thereby force-from the Christian tradition. There is, one might say, something of an Old Testament impatience in the poem's question "Who are you, standing turned away?" But these similarities are limited to the question and the uncertainty. In other respects and taken as a whole, the poem is, as I see it, very remote from the world of the bible.

To interpret the "you" of the poem as God would be to go beyond Lagerkvist's sphere. If, for the present at least, we choose to remain within this sphere, we find that two other interpretations win support. I quote from a book of meditations, Man Freed (1939):

How I must have loved life. When I remember it, it is as one remembers a beloved woman from whom one is separated for ever.

[...] I cannot see her face. Because she is walking away. I see only the actual figure. And she does not turn round.

Perhaps life no longer has any face for $\mathrm{me}^{\tau}$.

From this text, and others which space does not allow me to quote, is derived an interpretation implying that the "you" of the poem is a woman who is life. The content of the poem can be summarised as follows: we may never see the secret of life and we cannot comprehend it rationally, but one day we will be one with it, as a man is united with a woman he loves.

Another interpretation, however, is hardly less justified with reference to Lagerkvist's works. Here too I must be content with a single example. In The Holy Land, one of his last books (1964), we are told how Tobias the pilgrim, having passed the three crosses (which are all empty), comes to the bank of a river. He sees a man standing by the bank "turned away, right over the gliding water, as if sunk in contemplation of it".

He went up and stood at his side. Looked down into the water like him. Saw his own face reflected there, but old, aged, with greying hair, he hardly recognised it. Saw that it was his own face reflected there, and only his. That he was alone, and that there was no-one else but him. That the stranger was himself ${ }^{8}$.

The poem from Genius can now be interpreted by analogy with this and other Lagerkvist texts. The answer to the question, Who are you, standing turned away? is: my true self, with which I shall one day be united, and then-perhaps in the presence of death-I shall become whole.

Both of the interpretations I have suggested are well supported. However, it is required that we supplement the text with motifs from other texts, albeit by the same author. If we confine ourselves to this short poem alone, 
without thought of what Lagerkvist has written elsewhere, it is doubtful whether these nine lines can sustain such elaborate interpretations as those suggested, and such interpretations are not needed either. The poem about the figure turned away has a meaning, nonetheless. What matters in it lies at a level where there are as yet no labels, a psychological level where theoretical concepts have yet to be formulated, or where-in the face of eternity-they have been set aside as unimportant.

If, however, we feel the need to interpret the poem further than this (to fill out its 'Unbestimmtheitsstellen', to borrow Ingarden's term), there is, on the other hand, no obligation to choose precisely Lagerkvist's personal system of symbols as our norm for interpretation. That his poem is meaningful, even when set in another symbolic system likely to be quite for eign to Lagerkvist, was demonstrated by a Swedish critic, Gunnar Edman, a few years ago in a television programme based on "Who are you, standing turned away?". Edman there tried to see the unknown figure as Christ or as a reminder of him. Because of its indeterminacy, Edman might have claimed in support of his interpretation, the text points in this direction too. It is difficult to offer anything against this.

I have tried by my examples to provide a reminder that the believing author (or reader) is not confined to any specific language. Thus Dostoyevsky talks of "life" when he suggests a central religious mystery, and in Lagerkvist's poem about the turned away figure, a Christian critic can glimpse Christ. On the other hand we have seen how authors whom it would not be plausible to call Christian use the language of faith.

Similar cases could be cited in large numbers. Literary symbols seem to have the capacity to cross borders unchecked over the whole religious continent. But this gives us no reason to proclaim that, among writers using symbols, there is no division between believers and non-believers.

Such an opinion would mean that all authors (if they only speak with sufficient seriousness) would appear to be brothers-admittedly not in faith, but brothers in their religious attitude, and beyond this we should have no need for any distinctions. I find such a muddled view unappealing.

But if, then, the division must be attempted, the difficulty of accomplishing it is considerable. When we confine ourselves to the "lexical level" of the symbolic language (Ricœur), that is, only study the individual symbols or very small units of text, the borderline is often invisible; I refer to the examples above. If, however, we leave this plane and direct our attention to larger symbolic structures, it may be possible to distinguish who is a Christian believer and who holds some other sort of belief. By "larger" structures, I here mean those which emerge, for example, in a writer's work, or at any rate over a whole period of his development.

The first point about these comprehensive structures is that they offer us rules for interpreting the individual text. To return to the Lagerkvist poem: it is not plausible to read "Who are you, standing turned away?" as referring 
to Christ. I do not need to repeat that no law exists enforcing the application of this rule for interpretation. There are, on the other hand, good reasons for applying it, although the ultimate choice is the reader's.

In the second place, one can usefully reverse the perspective and look for rules which govern creation, and this I find even more interesting. One then begins with a writer's religious belief as given and attempts to show how this governs the creative process. The word "govern" must of course be construed very freely. There is no necessary relationship, either logical or psychological, between belief and art. What I have in mind is a tendency implying-if, for example, we confine ourselves to a poet talking of deaththat certain symbols with reference to his belief or lack of belief can seem natural, even expected, and others not. It would be strange if the believer and the non-believer consistently spoke the same langauge on such questions. What to one is the hope giving meaning to existence, is to the other an illusion. The choice and deployment of poetic symbols may be assumed to be dominated by this relationship. The writer's belief could then be said to function as a sort of deep structure, from which the shape of the symbolic language in the surface structure is derived.

But then again, this is an extremely vague metaphor. Artistic creation is a complicated process, and it is by no means certain that a writer's belief (however sincerely it may be held) governs his writing in such a manner as to permit generalisations even within the frame of his own work. I do not therefore wish to launch any model, however hypothetical, for the relationship between belief and literary creation. I am content to emphasise that here is an area worthy of more systematic study than it has hitherto received.

I have so far postponed one question of fundamental importance to my argument, or only touched upon it: what does it mean to have a belief and one which, within the terms of my discussion, can be called Christian? Obviously the fact that an author produces texts which can be understood by others as expressions of Christian faith is not a sufficient criterion where he is concerned. Even less is it a criterion of belief that the reader-albeit with admiration and involvement-utilises such texts.

Let me introduce a new example, Bertil Malmberg's drama His Excellency (written in 1938 and published in 1942). It takes place in Austria after the Anschluss, and the main character is a great Catholic poet. He is offered the chance to flee from the country, but refuses it and chooses to remain. He dies in a concentration camp, as a martyr. There is a good reason for calling this an unmistakably Christian drama. What conclusions can we draw form it regarding the author's own belief? In his memoirs, A Writer's Life (1952), Malmberg claims that His Excellency is not only, or even principally a political drama. It also, and above all, portrays a "a writer's path from the chill of perfection, from the melancholy in form and pleasure-seeking, through catastrophe and martyrdom, to experience of 
Christ". Malmberg goes on to say that personally he had no such experience "but I made my protagonist undergo it".

So I experienced this miracle in my imagination, as a poet, only as a poet, not as a believer, but it took place with an intensity of illusion (for me). It was my own path as a true Christian that I was hypothetically covering, and when it was completedwell, then I found I was still at the point where I started ${ }^{9}$.

One should note that these lines were written many years later, when Malmberg had abandoned his Christian commitment. It is conceivable that at this later stage he wished to play down the seriousness of the faith he had professed for a short period of his life. In this case, should we not perhaps regard the drama itself as more reliable testimony than this retroactive denial? Malmberg's example shows us again how much easier it is to determine the religious content of a literary text than it is to determine what the author himself believed.

At this point, under the influence of methodical rigour, it would be tempting to resign. That is to say stop talking altogether about authors' beliefs and instead limit oneself strictly to gauging the religious content of their writing. Artistic texts can of course be incomparably richer and more expressive than other texts, but they provide unreliable "source material". For to the extent that literary creation is characterised by play, acting and the quest for effect, the value of the product as a source correspondingly diminishes when we attempt to reach what may be called the writer's own beliefs.

It is salutary if such a reflection takes the colour from our cheeks. I believe, however, that resignation at this point would be an unreasonable expedient. We must still start from the assumption that the authors we study hold some sort of belief (Christian or non-Christian, the variations here are innumerable). In this they resemble people in general. We assume that the latter believe in something, although these beliefs can change in the course of their lives and often co-exist with doubt or uncertainty. Provided such a general view is legitimate, it would be most remarkable if just authors (perhaps together with other artists) constituted a special group, removed from the rest of humanity. Those who nonetheless believe this to be the case, should give their reasons for this opinion; the burden of proof rests on them.

How then is one to describe the difference between believing and expressing a belief one does not share? I imagine that the essential difference should be seen as resting in the attitude towards the truth of the symbol or statement of belief. In addition, at least as far as the Christian faith is concerned, there is also a moral obligation which is a consequence of faith. Furthermore, there is the sense of communion with those who embrace the same faith. But the ultimate criterion for me still seems to be the question of truth.

${ }^{9}$ Malmberg 1952, $156 \mathrm{ff}$. 
The title of my talk may be understood as referring to two different areas: firstly, the internal relationship between the belief the work as a whole can be said to express, and the symbolism of the work. This question has not been the main focus of my argument. What I have been most concerned to emphasise is a second relationship, that existing between a writer's belief and his work. I have thereby assumed-to state once again the premise of my argument-that writers, like other people, may be supposed to possess beliefs of some kind. Inasmuch as this assumption is valid, the question arises of what role a writer's belief plays in his choice of symbols and his deployment of them.

A fascinating field of research is opened up here. The literary scholar, however, is not equipped to explore it alone; he must be joined by the scholar of religion. With co-operation between people from these two disciplines, exciting things can happen.

\section{Bibliography}

\section{Stockholm}

Kungl. Biblioteket

Pär Lagerkvists samling (L 120)

Достоевский, Ф. М., 1958, Братья Карамазовы. Собрание сочинений, 9-10. Москва.

Lagerkvist, P., 1913, Ordkonst och bildkonst. Om modärn skönlitteraturs dekadans. Om den modärna konstens vitalitet [Word Art and Pictorial Art. On the Decadence of Modern belles lettres. On the Vitality of Modern Art]. Stockholm.

- 1914, Motiv [Motifs]. Stockholm.

- 1925, Gäst hos verkligheten [Guest of Reality]. Stockholm.

- 1937, Genius. Stockholm.

- 1939, Den befriade människan [Man Freed]. Stockholm.

- 1964, Det heliga landet [The Holy Land]. Stockholm.

Linnér, S., 1971, I marginalen till en Lagerkvistdikt. Lyrik $i$ tid och otid. Lyrikanalytiska studier tillägnade Gunnar Tideström 7.2.1971. Lund.

- 1975, Starets Zosima in The Brothers Karamazov. Acta Universitatis Stockholmensis. Stockholm Studies in Russian Literature, 4. Ekenäs.

Lundkvist, A., 1961, Agadir. En dikt. [Agadir. A Poem]. Stockholm.

Malmberg, B., 1942, Excellensen [His Excellency]. Stockholm.

- 1952, Ett författarliv [A Writer's Life]. Stockholm.

Psalmer, 1976. Psalmer och visor 76. Tillägg till den svenska psalmboken, 1. Lund. 